Research Article

\title{
Microbiological safety of Portuguese Dry-Fermented Chouriço Sausages as affected by Processing and Physicochemical Factors
}

\author{
Beatriz Nunes Silva ${ }^{1}$, Vasco Cadavez ${ }^{1}$, Preciosa Pires ${ }^{2}$, Teresa Dias and Ursula Gonzales-Barron ${ }^{\star}$ \\ 'CIMOMountain Research Centre, School of Agriculture, Polytechnic Institute of Braganza. Campus de Santa Apolónia, 5301-855 Bragança, Portugal \\ ${ }^{2}$ School of Technology and Management, Polytechnic Institute of Viana do Castelo, Viana do Castelo, Portugal
}

Article Info
*Corresponding author:
Ursula Gonzales-Barron
CIMO Mountain Research Centre
School of Agriculture, Polytechnic Institute
of Braganza
Campus de Santa Apolónia
5301-855 Bragança, Portugal
Tel: +351 273303325
E-mail: ubarron@ipb.pt

Received: October 18, 2018

Accepted: November 5, 2018

Published: November 12, 2018

Citation: Silva BN, Cadavez V, Pires P, Dias T, Gonzales-Barron U. Microbiological safety of Portuguese dry-fermented chouriço sausages as affected by processing and physicochemical factors. Madridge J Food Technol. 2018; 3(2): $137-148$

doi: $10.18689 / \mathrm{mjft}-1000121$

Copyright: @ 2018 The Author(s). This work is licensed under a Creative Commons Attribution 4.0 International License, which permits unrestricted use, distribution, and reproduction in any medium, provided the original work is properly cited.

Published by Madridge Publishers

\begin{abstract}
In order to identify the risk factors and main differences of the manufacturing technology of Portuguese chouriço dry-fermented sausage leading to the variable levels of Enterobacteriaceae, Staphylococcus aureus and Listeria monocytogenes in the product, microbiological and physicochemical characterisation of chouriço sampled at five stages of production was performed. Six production batches were surveyed from each of two factories, one of them used curing salts and polyphosphate in their formulation. The results suggest that mixing and maceration are critical points of the process since Enterobacteriaceae, S. aureus and L. monocytogenes could significantly increase until the end of such stages. Sausages formulated with nitrite and polyphosphate were found to have a delayed fermentation; which was responsible, to a certain extent, for the increase in Enterobacteriaceae and pathogens' counts from raw meat to the end of maceration. On the contrary, the better acidification process of nitrite-free sausages led to lower counts of $S$. aureus and L. monocytogenes in the final products. Nitrite had a strong effect on reducing Enterobacteriaceae during smoking and also contributed to the control of L. monocytogenes, while it showed no effect on the growth of $S$. aureus in chouriço. There is a need to standardise the traditional elaboration process of chouriço, to optimise the initial acidification process, and to guarantee the high microbiological quality of ingredients, sanitisation of equipment, and good hygiene practices of operators.
\end{abstract}

Keywords: Chorizo; dry-cured; survey; Enterobacteriaceae; Staphylococcus aureus; Listeria monocytogenes; curing salts; longitudinal models.

\section{Introduction}

In Europe, naturally-fermented sausages such as chouriço have been consumed for many centuries and are considered a gastronomic heritage from the Roman Era. Chouriço, in particular, is a popular fermented sausage made of raw, unground and salted pork meat. Due to its short ripening time (10 to 20 days) and final water activity (0.90 to 0.95), it is considered a 'semi-dry, no-mould-growth' fermented sausage, according to Lucke's classification of fermented sausages based on microbial stability [1]. Chouriço has its origins in temperate, maritime climates, as the traditional ripening process (which includes a fermentation stage) requires low to moderate temperatures, oppositely to other varieties of fermented meats that require higher temperatures and warmer climates. The production of chouriço starts by marinating diced pork meat in a mixture of water, salt, regional wine and spices, although some factories also include curing agents in the formulation. The following step, fermentation, is carried without the addition of starter cultures [2-4], as this process occurs spontaneously due to the natural occurring microflora. After few days of maceration, the mixture is filled into natural pork casings, and then smoked and ripened at low temperatures. 
Chouriço is mainly produced by small-scale, artisanal manufacturers. This means that, despite the general steps for the production of this sausage, each processing unit has its own traditional customs and techniques, which translates into final products with varying microbiological quality, stability and safety. Moreover, being an artisanal elaboration, it is expectable that the production process suffers accidental variations even within the same processing unit, as process variables such as temperature and time may not be fully controlled [5], thus generating some variability in quality from batch to batch. To this respect, a meta-analysis study on the incidence of pathogens in traditional Portuguese meat products revealed a variable occurrence of $L$. monocytogenes (8.30\%; 95\% Cl: $5.10-15.1 \%)$ and S. aureus (18.4\%; 95\% Cl: $9.00-33.9 \%$ ) in sausages 'intended to be eaten raw' [6], which includes chouriço.

At the moment, it is clear that the current production methods of chouriço need to be evaluated and improved. It is imperative to understand which risk factors can increase the microbiological quality and safety of this product and, at the same time, reduce the between-batch variability caused by poorly-controlled production processes. For this reason, in this study, microbiological surveys were conducted in two factories of dry-fermented chouriço sausages in order to: (i) reveal the differences in manufacturing technology that could explain the variable levels in Enterobacteriaceae, S. aureus and L. monocytogenes among production batches; (ii) assess relationships between physicochemical properties of the product $\left(\mathrm{pH}, \mathrm{a}_{\mathrm{w},}\right.$ moisture, nitrite, nitrate, polyphosphates and sodium chloride concentration) and microbial counts along processing; and (iii) rank the "critical" process variables or risk factors contributing to the current microbial contamination of chouriço sausages.

\section{Experimental}

\section{Sampling scheme}

Both physicochemical and microbiological longitudinal surveys of chouriço processing from raw meat to final product, as well as microbiological surveys of environmental elements, were carried out in two regional factories, located in the Northeast of Portugal. The number of sampling visits was sufficient to gather complete physicochemical, microbial and environmental profile data for twelve batches of production. In both factories, pork meat from Longissimus dorsi was macerated in water, red wine, garlic paste, piri-piri, sweet red pepper paste and laurel leaves at low temperature. Factory I did not utilise any additive in the formulation, while Factory II added curing salts (nitrite/nitrate) and polyphosphates in the macerating meat. Before the day of sausage stuffing, pork large intestine casings are washed and kept in salted water at refrigeration temperature until use. Macerated meat is then stuffed in the casings to obtain $\sim 20-\mathrm{cm}$ long horse-shape sausages. Vertically-hung sausages in racks are then subject to the drying effect of smoke produced by burning olive and oak tree firewood for 5-20 days in a smokehouse, whose ambient temperature is not controlled, yet can be between $40-55^{\circ} \mathrm{C}$. Sausages continue to ripen in a refrigerated chamber at low relative humidity, and are packed either under normal atmosphere or vacuum. Both factories were middle-sized and availed from the following distinct areas: meat cutting, mixing, filling and packaging rooms, smokehouse and refrigerated chamber.

Six production batches of chouriço per factory were followed up through systematic sampling of raw meat $(n=3$ units per batch), meat mixed with ingredients $(n=3)$, macerated meat $(n=3)$, smoked sausage $(n=5)$ and final product $(n=5)$ (Figure 1$)$. These sampling points along production are hereafter referred to as 'raw meat', 'mixed', 'macerated', 'smoked' and 'ripened', respectively. Within a batch, the day of sampling for both 'raw meat' and 'mixed' belonged to the same day of production (Day 0 ). However, because the duration periods of the processing stages of maceration (from 2 to 9 days), maturation and smoking (from 5 to 23 days) and ripening (from 2 to 10 days) were variable from batch to batch (even within the same factory), samples were taken always at the end of the processing stage, and the corresponding Day was annotated. Overall, while the processing time of chouriço produced in Factory I was 28-31 days, the one of Factory II was shorter, between 13-17 days.

In the sampling visits, swabs from six environmental elements, namely, table surface, transport trolleys, mixer, filler, knives and operator hands $(n=6)$ were also taken (Figure 1$)$. The six samples consisted of two environmental elements swabbed during processing from each of the following three rooms: meat cutting and mixing rooms, sampled on the day of mixing; and filling room sampled on the day that maceration was completed. For sampling one environmental element, a total surface area of $300 \mathrm{~cm}^{2}$ was swabbed. In the case of knives and operator hands, areas of $\sim 200 \mathrm{~cm}^{2}$ were swabbed. Environmental and product samples were transported to the lab and stored at $4^{\circ} \mathrm{C}$. They were processed before $24 \mathrm{~h}$ for microbiological analysis, or were promptly frozen $\left(-18^{\circ} \mathrm{C}\right)$ until use for physicochemical analyses

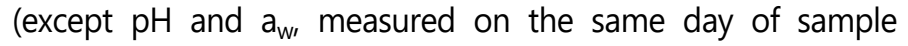
collection). Microbiological determinations of total viable counts (TVC), Enterobacteriaceae, S. aureus and L. monocytogenes were performed in meat samples and environmental elements. Physicochemical determinations in meat samples encompassed $\mathrm{pH}, \mathrm{a}_{\mathrm{w}}$ moisture, sodium nitrite, potassium nitrate, phosphorous and sodium chloride contents.

In addition, while the processes of meat cutting, mixing and stuffing took place, the ambient temperature and relative humidity of each of these rooms were recorded by a thermohygrometer transmitter (TFA ${ }^{\circledR}$ Dostmann, Wertheim, Germany) at five different sites within a room (Figure 1). Average ambient temperatures of these three rooms were then calculated for each of the production batches.

\section{Microbiological analyses}

In the laboratory, all sausage casings were removed using sterilised instruments to produce sausage samples. For the microbial determinations, $25 \mathrm{~g}$ of sample was diluted in $225 \mathrm{~mL}$ sterile buffered peptone water (BPW, VWR Chemicals Prolabo, Portugal) and homogenised for 2 min (Stomacher 400, Seward, UK). For the analysis of an environmental element, the solutions from the three swab tubes were mixed, and a $4 \mathrm{~mL}$-volume was 
taken and diluted in $36 \mathrm{~mL}$ BPW. For TVC, 1-mL volumes from sampling dilutions were spread onto Aerobic Count Plate Petrifilm ${ }^{\mathrm{TM}}$ disks (3M Health Care, St. Paul, USA), and incubated at $30^{\circ} \mathrm{C}$ for $72 \mathrm{~h}$. For Enterobacteriaceae, 1 -mL volumes were spread onto Enterobacteriaceae Count Plate Petrifilm ${ }^{\mathrm{TM}}$ disks, and incubated at $37^{\circ} \mathrm{C}$ for $24 \mathrm{~h}$. For S. aureus, $1-\mathrm{mL}$ volumes were spread on Petrifilm ${ }^{\mathrm{TM}}$ Staph Express Count, incubated at $37^{\circ} \mathrm{C}$ for $24 \mathrm{~h}$, and coagulase-positive colonies confirmed with Petrifilm ${ }^{\text {TM }}$ Staph Express Disk, according to the manufacturer's instructions.

For the microbiological analysis of L. monocytogenes, $25 \mathrm{~g}$ of sample was homogenised for 2 min in $225 \mathrm{~mL}$ of Half Fraser Base CM0895 (Oxoid, Hampshire, UK). The enumeration was performed according to the ISO 11290-2:1998/Amd. 1:2004(E) procedure [7]. After incubation of the initial suspension for $1 \mathrm{~h}$ at $20^{\circ} \mathrm{C}$, a $0.1-\mathrm{mL}$ volume was surface-inoculated on Oxoid Chromogenic Listeria Agar (OCLA, Oxoid) and incubated at $37^{\circ} \mathrm{C}$ for $24 \mathrm{~h}$. The samples with no growth were analysed for detection of $L$. monocytogenes according to the ISO 11290-1:1996/Amd.1:2004(E) procedure [8]. The initial suspension was supplemented with SR 166 selective supplement (Oxoid), incubated at $30^{\circ} \mathrm{C}$ for $24 \mathrm{~h}$ and streaked on OCLA (incubated at $37^{\circ} \mathrm{C}$ for $24 \mathrm{~h}$ ). If no growth was detected, 0.1 $\mathrm{mL}$ of the same initial supplemented suspension was transferred into 10-ml Fraser Broth supplemented with SR 166 (Oxoid), incubated at $37^{\circ} \mathrm{C}$ for $48 \mathrm{~h}$ and streaked onto OCLA (incubated at $37^{\circ} \mathrm{C}$ for $24 \mathrm{~h}$ ). The colonies that grew on OCLA were confirmed with additional tests of haemolysis, catalase reaction, Gram stain and motility. The presumptive colonies of Listeria spp. were confirmed using API ${ }^{\circledR}$ Listeria (bioMérieux, Marcy l'Etoile, France) biochemical strips according to manufacturer's instructions. The microbiological determinations per sample were carried out in duplicate. Microbial results were expressed in log CFU/g (products) and log CFU/ $/ \mathrm{cm}^{2}$ (environments) for all microbial groups with exception of $L$. monocytogenes, where CFU/g and $\mathrm{CFU} / \mathrm{cm}^{2}$ were used, respectively.

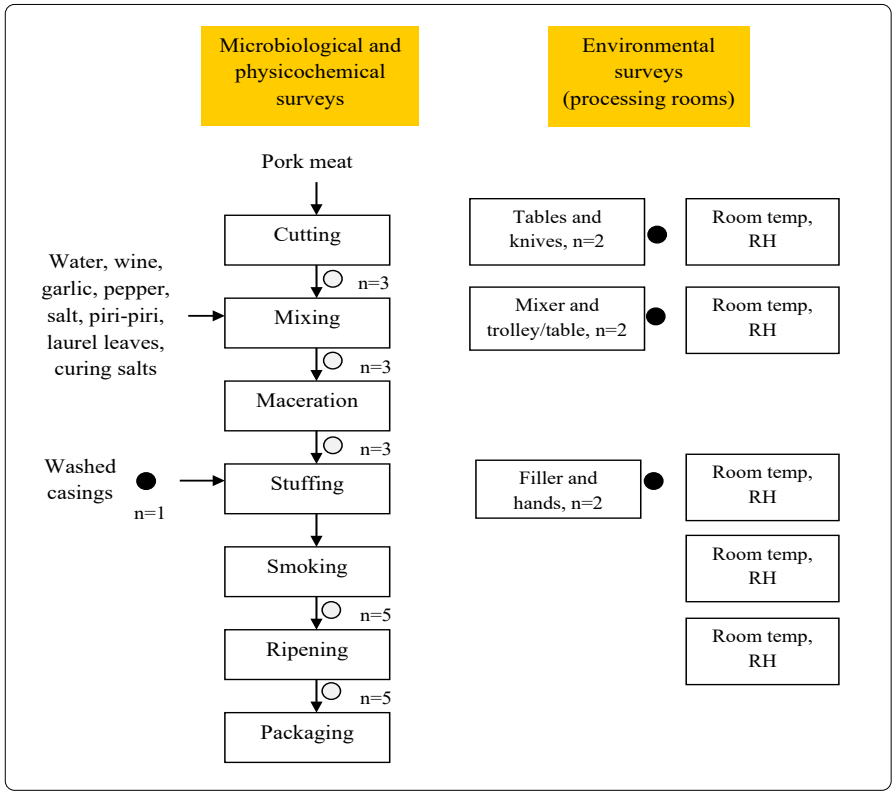

Figure 1. Flow diagram of chouriço sausage processing showing sampling sites for microbiological analyses (TVC, Enterobacteriaceae, S.

aureus and $L$. monocytogenes in points $O O$ ) and physicochemical

analyses $\left(a_{w}, \mathrm{pH}\right.$, moisture, sodium nitrite, potassium nitrate, phosphorous and sodium chloride in points) from a production batch.

\section{Physicochemical analyses}

The $\mathrm{pH}$ was measured directly in the centre of the samples with a pH-meter HI8424 (Hanna Instruments, Portugal) while $a_{w}$ was measured using a HygroPalm AW1 (Rotronic International, Portugal). Moisture and sodium chloride content $(\mathrm{NaCl})$ were quantified according to the ISO recommended standards 1442:1997 [9] and 1841-1:1996 [10], respectively. Nitrites and nitrates were quantified according to ISO 2919:1975 and ISO 3091:1975 [11,12], and expressed as sodium nitrite $\left(\mathrm{NaNO}_{2}\right)$ and potassium nitrate $\left(\mathrm{KNO}_{3}\right)$, respectively. Total phosphorus was quantified following AOAC 969.31 [13] and the molecular absorption spectrophotometric method from SMEWW 4500P-E [14]. Phosphorous was expressed as phosphorus pentoxide $\left(\mathrm{P}_{2} \mathrm{O}_{5}\right)$. All physicochemical determinations were made in triplicate for each sample.

\section{Statistical analyses}

Variables defined for data analyses encompassed microbial groups (TVC, Entero, Staphy and Listeria) and physicochemical properties $\left(\mathrm{pH}, \mathrm{a}_{\mathrm{w}}\right.$ moisture, $\mathrm{NaCl}, \mathrm{NaNO}_{2}$, $\mathrm{KNO}_{3}$ and $\mathrm{P}_{2} \mathrm{O}_{5}$ ), as mentioned above. In addition, other variables were defined using the data generated in a production batch: Factory (either I or II), Day (day of sampling at the end of a processing stage, as detailed in Subsection 2.1), Stage (either meat, mixed, macerated, smoked or ripened), MeanTVCEnv, MeanEnteroEnv, MeanStaphyEnv and MeanListeriaEnv (mean environmental contamination for each bacterial group calculated as the average of the 6 environmental samples within a batch), RoomTVCEnv (mean TVC counts of the environmental elements sampled in the cutting, mixing and filling room within a batch), RoomEnteroEnv (same as above for Enterobacteriaceae), RoomStaphyEnv (same as above for S. aureus), RoomListeriaEnv (same as above for L. monocytogenes), and RoomT and RoomRH (mean ambient temperature and relative humidity of the meat cutting, mixing and filling rooms within a batch). Due to the typical moisture loss during the manufacturing process, the concentrations of all chemical compounds in the meat/ sausage samples were converted to dry matter ( $\mathrm{dm}$ ). These variables were defined as $\mathrm{NaCldm}, \mathrm{NaNO}_{2} \mathrm{dm}, \mathrm{KNO}_{3} \mathrm{dm}$ and $\mathrm{P}_{2} \mathrm{O}_{5} \mathrm{dm}$. Three types of statistical analysis were then carried out, as described below.

\section{Analysis I: Associations between physicochemical properties and microbial counts along processing}

The objective of this analysis was to appraise the particularities in the evolution of the physicochemical parameters that could partially explain the batch-specific differences in microbial concentrations along production. $T V C_{i j k}=\beta_{0}+\beta_{1 i} D a y\left(S t a g e_{i}\right)+\beta_{2} a_{W}+\beta_{3} p H+\beta_{4} N a N O_{2} d m+\beta_{5} p H \times N a N O_{2} d m+\varepsilon_{j(k)}(1)$

Enter $_{i j k}=\beta_{0}+\beta_{11} D$ Day $\left(\right.$ Stage $\left._{i}\right)+\beta_{2} a_{W}+\beta_{3} p H+\beta_{4} N a N O_{2} d m+\beta_{5} p H \times N_{N N O} d m+\varepsilon_{j(k)}(2)$ Staphy $_{i j k}=\beta_{0}+\beta_{1 i} D_{\text {Day }}\left(\right.$ Stage $\left._{i}\right)+\beta_{2} a_{w}+\beta_{3} \mathrm{PH}+\beta_{4} \mathrm{NaNO}_{2} d m+\beta_{5} \mathrm{PH} \times \mathrm{NaNO}_{2} d m+\varepsilon_{j(k)}(3)$

The following general linear models were adjusted separately to the TVC, Enterobacteriaceae and S. aureus data sets. The covariance of the error term $\varepsilon_{j(k)}$ is unstructured and thus allows for dependence of the observations within batches of production $k$, yet nested within factories $j$. Likewise, because the number of 
days (Day) of a processing stage i (Stage) was different from batch to batch, a nested term Day (Stage $i)$ was pondered in order to withdraw the effect of stage duration. Stage was included in the linear models to extract the individual effects of mixing with other ingredients, maceration, smoking and ripening; and, in this manner, to evaluate the effects of $\mathrm{a}_{\mathrm{w}} \mathrm{pH}$ and nitrite $\left(\mathrm{NaNO}_{2}\right)$ in a global way. As the interaction between $\mathrm{pH}$ and nitrite proved to be significant, the term was included in all models above.

As the untransformed L. monocytogenes data (CFU/g) was over-dispersed (variance >>mean due to the low microbial counts and large proportion of zero counts), a Poissongamma (negative binomial) count data model was opted for. Earlier, Gonzales-Barron et al. [15] demonstrated that this type of count data models along with their zero-modified counterparts are much more suitable for inferential assessment than normality-based regression models when analysing over-dispersed microbiological data. Thus, in order to appraise the same fixed effects as in Equations (1-3), yet taking up the non-detections, a regression model based on the Poisson-gamma distribution was fitted to the $L$. monocytogenes data,

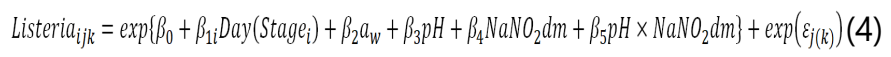

where the errors $\varepsilon_{j(k)}$ follow a gamma distribution $(1 / \theta, \theta)$ with expected value 1 and dispersion parameter $\theta$. For a detailed description of the Poisson-gamma regression, refer to Gonzales-Barron et al. [15].

\section{Analysis II: Impact of processing days and environmental contamination on microbial counts along production}

The objective of this statistical analysis was to evaluate the mean effects of the duration of a processing stage and the environmental contamination/temperature of a processing room on the microbial concentrations along production.

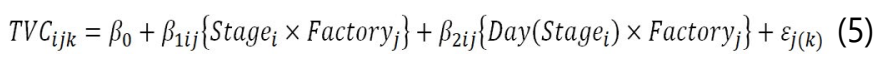

$$
\begin{aligned}
& \text { Entero }_{i j k}=\beta_{0}+\beta_{1 i j}\left\{\text { Stage }_{i} \times \text { Factory }_{j}\right\}+\beta_{2 i j}\left\{\text { Day }_{\left.\left(\text {Stage }_{i}\right) \times \text { Factory }_{j}\right\}+\varepsilon_{j(k)}(6)}\right.
\end{aligned}
$$

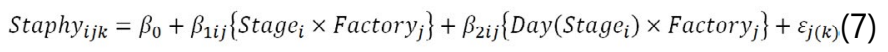

The longitudinal models of the form, were fitted to the counts of TVC (Equation 5), Enterobacteriaceae (Equation 6) and $S$. aureus (Equation 6) as response variables. The categorical

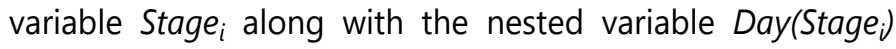
were included in the model to estimate the mean increase or decrease in microbial concentration per day of maceration, smoking and ripening (represented by the fixed-effects $\beta_{2 i}$ in Equations (5-7)). As the stage-specific day slopes $\beta_{2}$ may differ between factories (known a priori because Factory I produces sausages in longer time than Factory I), the categorical variable Factory ${ }_{j}$ was allowed to enter in interaction with both Stage $_{i}$ and Day $\left(\right.$ Stage $\left._{i}\right)$.

For the L. monocytogenes data, a Poisson-gamma regression model was adjusted, although with a slightly different structure.Since for Factory I, L. monocytogenes counts took mostly values of either 0 or $50 \mathrm{CFU} / \mathrm{g}$, it was not possible to estimate the effect of day $\beta_{2}$ per factory. Thus, the terms Factory $_{j}$ in interactions with Stage $_{i}$ and Day $\left(\right.$ Stage $\left._{i}\right)$ had to be dropped from the model, and its parameter estimates were assumed to be applicable to both factories.

Listeria $_{i j k}=\exp \left\{\beta_{0}+\beta_{1 i}\left\{\right.\right.$ Stage $\left._{i}\right\}+\beta_{2 i}\left\{\right.$ Day $\left(\right.$ Stage $\left.\left.\left._{i}\right)\right\}\right\}+\exp \left(\varepsilon_{j(k)}\right)$

To assess the effects of environmental contamination and ambient temperature/RH on the TVC counts along processing, the variables MeanTVCEnv, RoomTVCEnv, RoomT and RoomRH were added one by one to Equation (5) and their significance tested. Likewise, the significances of the corresponding environmental variables for Enterobacteriaceae (MeanEnteroEnv, RoomEnteroEnv and RoomT), S. aureus (MeanStaphyEnv, RoomStaphyEnv, RoomT and RoomRH) and L. monocytogenes (MeanListeriaEnv, RoomListeriaEnv,RoomT and RoomRH) were tested by linearly adding them, one by one, to Equations (6), (7) and (8), respectively.

\section{Analysis III: Factors favouring the growth/survival of Enterobacteriaceae and pathogens during processing}

The objective of the last type of statistical analysis was to identify the main (risk) factors that contributed to the growth or survival of Enterobacteriaceae, S. aureus and L.monocytogenes in chouriço at the end of maceration, smoking and ripening. Considering all the information extracted from the surveys, the factors likely to have an effect on the final microbial counts were defined, as follows (independent variables): raw meat $\mathrm{pH}$, concentrations of nitrite and nitrate added at maceration, Enterobacteriaceae/S. aureus/L. monocytogenes counts in raw meat, Enterobacteriaceae/S. aureus/L. monocytogenes after mixing with ingredients, mean Enterobacteriaceae/S. aureus/L. monocytogenes from environmental elements, $\mathrm{a}_{\mathrm{w}} / \mathrm{pH} / \mathrm{moisture/}$ $\mathrm{NaCl}$ at the end of maceration, $\mathrm{a}_{\mathrm{w}} / \mathrm{pH} / \mathrm{moisture} / \mathrm{NaCl}$ at the end

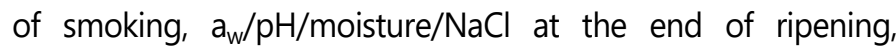
duration of maceration, duration of smoking, duration of ripening, mean temperature of mixing room and mean temperature of filling room. For every bacterial group, three separate stepwise variable selection analyses were performed using the microbial concentration at the end of maceration, smoking or ripening as dependent variables, and all of the factors specified above as independent variables. The significance level for an effect to enter and to stay in the model was set to 0.25 . All models described were adjusted in the SAS software (version 9.1.3) [16] while graphs were created in $R$ (version 2.14.2) [17].

\section{Results and Discussion}

The surveys evidenced a great variability in the evolution of physicochemical properties and microbial counts both among production batches and between industries, which was partly due to the variable manufacturing process. For instance, for the batches sampled, intermittent smoking took $5,7,18,19$ or 23 days while ripening took $2,5,7$ or 10 days.

\section{Physicochemical changes along chouriço processing}

The physicochemical properties of chouriço sausages produced by both factories revealed some differences (Table 1) that are not only associated to the distinct manufacture methods but also to the addition of curing salts (nitrite and 
nitrate) and polyphosphates by Factory II (that Factory I did not use). The addition of such additives to the product in Factory II is easily deduced by the significant increase in $\mathrm{NaNO}_{2}, \mathrm{KNO}_{3}$ and $\mathrm{P}_{2} \mathrm{O}_{5}$ on a wet basis (wb) from the raw meat stage $(0.055 \mathrm{mg} / \mathrm{kg} \mathrm{wb}, 4.974 \mathrm{mg} / \mathrm{kg} w b$ and $0.491 \%$ $\mathrm{wb}$, respectively) to the next sampling point, mixed (8.549 $\mathrm{mg} / \mathrm{kg} \mathrm{wb}, 139.2 \mathrm{mg} / \mathrm{kg} \mathrm{wb}$ and $0.620 \% \mathrm{wb}$, respectively) (Table 1). The concentrations of such additives significantly increased in the following sampling stages (macerated meat, and smoked and ripened sausages). Since they were calculated in a wet basis, this increase points out, in fact, the significant moisture loss occurring progressively during smoking and ripening (from $72.0 \%$ and $68.6 \%$ moisture at the end of maceration to $41.7 \%$ and $54.1 \%$ in final products from Factories I and II, respectively) and does not imply further addition of additives during those stages.

In comparison to Factory I, the sausages produced by Factory II revealed higher moisture retention $(54.1 \% \mathrm{wb})$ and accordingly, higher mean $\mathrm{a}_{\mathrm{w}}$ at the end of the smoking and ripening steps ( 0.941 and 0.930 , respectively). Such results are due to the shorter ripening period in Factory II and the use of polyphosphate in the product's formulation, which increases the water-binding capacity of fermented meats. This additive acts as polyelectrolytes to increase ionic strength, thus freeing some of the negatively-charged sites on the proteins so they can bind more water [18], and it can be used to prevent autooxidation and decrease purges in vacuum-packaged products. However, in cured meats particularly, the ionic strength increase mentioned above has an undesired $\mathrm{pH}$ rising effect [18]: while chouriço sausages from Factory I presented a continuous decline in $\mathrm{pH}$ from raw meat until the end of ripening, sausages produced by Factory II experienced a significant increase in $\mathrm{pH}$ (6.269) at the point of mixing (when polyphosphate is added), which was sustained until the end of maceration (6.263). The sausages' $\mathrm{pH}$ started dropping from smoking onwards, although their mean values at the end of smoking (6.016) and ripening (5.815) were still higher than the $\mathrm{pH}$ of sausages produced by Factory I (5.321 and 5.369, respectively; Table 1). Overall, in fermented meats, a high $\mathrm{pH}$ of the product at the mixing point will lead to higher final $\mathrm{pH}$ values, as described by Lucke [1] and observed here in particular for chouriço. Greater final $\mathrm{pH}$ values facilitate the growth of acid-sensitive undesired microorganisms such as Salmonella spp. and S. aureus in the product, meaning that a process that does not ensure an early and rapid production of acid (i.e. the process used by Factory II) might be unsafe.

Knowing that the product's final $\mathrm{pH}$, in both cases (Factory I: 5.369; Factory Il: 5.815), is higher than the $\mathrm{pH}$ for suppressing the growth of Salmonella spp. and S. aureus (5.3; [19]) it is critical to ensure that the time and temperature at which the macerating meat remains above the $\mathrm{pH}$ of 5.3 can guarantee the non-growth of such pathogens. According to good manufacturing practices developed by the American Meat Institute [20], the time that the sausage meat is exposed to temperatures above $15^{\circ} \mathrm{C}$ before $\mathrm{pH} 5.3$ is reached should be limited. In this sense, as this $\mathrm{pH}$ value is not reached, chouriço sausages should be ripened and stored below $15^{\circ} \mathrm{C}$ for safety reasons.

Another fact that may have contributed to problems during fermentation was the high $\mathrm{pH}$ of the raw meats used (6.04, SD = 0.06; Table 1) since, ideally, pork meat should have a normal pH (5.5-5.8) [2]. A poor production of organic acids caused by unsatisfactory fermentation will have an impact on the $\mathrm{pH}$ decrease that is necessary for the release of meat's moisture in a quick and uniform way. Even though the evolution of $a_{w}$ could be considered as normal in both factories (Table 1), it was only after maceration that a significant decrease occurred (due to the higher temperatures during smoking and the lower relative humidity and stable dehydration during ripening). In any case, the sausages produced by Factory II still presented higher $\mathrm{a}_{\mathrm{w}}(0.941$ after smoking and 0.930 after ripening) than Factory I (0.929 and 0.914 , respectively), reflecting the addition of polyphosphate and shorter processing time. Overall, chouriço sausages were dried to a moisture content of $48 \%$ and a final $a_{w}$ of 0.92 that, despite the higher than desirable $\mathrm{pH}$ values, are expected to contribute to the protection of the product against undesirable microorganisms [21]. The mean values of the physicochemical properties in mid-products and products from the two factories are also displayed in Table 1.

Table 1. Evolution of physicochemical characteristics of dry-fermented chouriço sausages along processing per factory and overall. Means and standard deviations (in brackets) are shown.

\begin{tabular}{|c|c|c|c|c|}
\hline $\begin{array}{l}\text { Physicochemical } \\
\text { property }\end{array}$ & Stage & $\begin{array}{c}\text { Factory I } \\
\text { (low nitrites) }\end{array}$ & \begin{tabular}{|c|} 
Factory II \\
(high nitrites)
\end{tabular} & Both Factories \\
\hline $\mathrm{pH}$ & \begin{tabular}{|l|} 
Raw meat \\
Mixed \\
Macerated \\
Smoked \\
Ripened
\end{tabular} & $\begin{array}{l}6.027(0.049) \mathrm{a} \\
5.759(0.049) \mathrm{a} \\
5.634(0.049)^{\mathrm{b}} \\
5.321(0.040) \mathrm{c} \\
5.369(0.041) \mathrm{c}\end{array}$ & $\begin{array}{l}6.045(0.065) \mathrm{a} \\
6.269(0.065)^{\mathrm{b}} \\
6.263(0.065)^{\mathrm{b}} \\
6.016(0.050)^{\mathrm{b}} \\
5.815(0.050)^{\mathrm{d}}\end{array}$ & $\begin{array}{l}6.036(0.060)^{\mathrm{a}} \\
6.014(0.060)^{\mathrm{a}} \\
5.949(0.060)^{\mathrm{a}} \\
5.680(0.048)^{\mathrm{b}} \\
5.607(0.049)^{\mathrm{b}}\end{array}$ \\
\hline$a_{w}$ & \begin{tabular}{|l|} 
Raw meat \\
Mixed \\
Macerated \\
Smoked \\
Ripened
\end{tabular} & $\begin{array}{l}0.980(0.003)^{a} \\
0.972(0.003)^{b} \\
0.969(0.003)^{b} \\
0.929(0.002)^{c} \\
0.914(0.002)^{d}\end{array}$ & $\begin{array}{l}0.976(0.004)^{\mathrm{a}} \mathrm{a} \\
0.953(0.004)^{\mathrm{b}} \\
0.956(0.004)^{\mathrm{b}} \\
0.941(0.003)^{\mathrm{c}} \\
0.930(0.003)^{\mathrm{d}}\end{array}$ & $\begin{array}{l}0.978(0.002)^{\mathrm{a}} \\
0.963(0.002)^{\mathrm{b}} \\
0.963(0.002)^{\mathrm{b}} \\
0.936(0.001)^{\mathrm{c}} \\
0.923(0.001)^{\mathrm{d}}\end{array}$ \\
\hline $\begin{array}{l}\text { Sodium nitrite } \\
\text { (mg/kg wb) }\end{array}$ & $\begin{array}{l}\text { Raw meat } \\
\text { Mixed } \\
\text { Macerated } \\
\text { Smoked } \\
\text { Ripened }\end{array}$ & $\begin{array}{l}0.068(0.086)^{a} \\
0.083(0.085)^{a} \\
0.094(0.085)^{a} \\
0.979(0.068)^{b} \\
1.134(0.071)^{c}\end{array}$ & $\begin{array}{l}0.055(0.902)^{\mathrm{a}} \\
8.549(0.902)^{\mathrm{b}} \\
5.016(0.902)^{\mathrm{c}} \\
8.133(0.700)^{\mathrm{d}} \\
6.913(0.700)^{\mathrm{d}}\end{array}$ & $\begin{array}{l}0.062(0.686)^{\mathrm{a}} \\
4.316(0.686)^{\mathrm{b}} \\
2.555(0.686)^{\mathrm{c}} \\
4.680(0.541)^{\mathrm{d}} \\
4.230(0.550)^{\mathrm{d}}\end{array}$ \\
\hline \begin{tabular}{|l} 
Potassium nitrate \\
$(\mathrm{mg} / \mathrm{kg} \mathrm{wb})$
\end{tabular} & $\begin{array}{l}\text { Raw meat } \\
\text { Mixed } \\
\text { Macerated } \\
\text { Smoked } \\
\text { Ripened }\end{array}$ & $\begin{array}{l}4.330(2.242)^{a} \\
7.943(2.307)^{b} \\
8.271(2.242)^{b} \\
21.00(1.797)^{c} \\
20.20(1.865)^{c}\end{array}$ & $\begin{array}{l}4.974(5.917)^{\mathrm{a}} \\
139.2(5.917)^{\mathrm{b}} \\
147.1(5.917)^{\mathrm{b}} \\
193.5(4.584)^{\mathrm{b}} \\
230.6(4.584)^{\mathrm{d}}\end{array}$ & $\begin{array}{l}4.652(13.65)^{\mathrm{a}} \\
75.42(13.84)^{\mathrm{b}} \\
77.68(13.65)^{\mathrm{b}} \\
110.2(10.75)^{\mathrm{c}} \\
132.9(13.65)^{\mathrm{c}}\end{array}$ \\
\hline $\begin{array}{l}\begin{array}{l}\text { hosphate as } \mathrm{P}_{2} \mathrm{O}_{5} \\
(\% \mathrm{wb})\end{array}\end{array}$ & $\begin{array}{l}\text { Raw meat } \\
\text { Mixed } \\
5 \text { Macerated } \\
\text { Smoked } \\
\text { Ripened }\end{array}$ & $\begin{array}{l}0.437(0.025)^{a} \\
0.383(0.025)^{a} \\
0.355(0.025)^{a} \\
0.562(0.021)^{b} \\
0.650(0.025)^{c}\end{array}$ & $\begin{array}{l}0.491(0.016)^{a} \\
0.620(0.016)^{\mathrm{b}} \\
0.618(0.016)^{\mathrm{b}} \\
0.744(0.012)^{\mathrm{b}} \\
0.867(0.012)^{\mathrm{d}}\end{array}$ & $\begin{array}{l}0.464(0.022)^{\mathrm{a}} \\
0.501(0.022)^{\mathrm{a}} \\
0.486(0.022)^{\mathrm{a}} \\
0.656(0.018)^{\mathrm{b}} \\
0.767(0.018)^{\mathrm{c}}\end{array}$ \\
\hline $\begin{array}{l}\text { Sodium chloride } \\
(\% \mathrm{wb})\end{array}$ & \begin{tabular}{|l|} 
Raw meat \\
Mixed \\
Macerated \\
Smoked \\
Ripened
\end{tabular} & $\begin{array}{l}0.084(0.085)^{a} \\
0.945(0.085)^{b} \\
1.149(0.085)^{b} \\
1.894(0.068)^{c} \\
2.177(0.072)^{d}\end{array}$ & $\begin{array}{l}0.090(0.061)^{\mathrm{a}} \\
1.641(0.061)^{\mathrm{b}} \\
1.747(0.061)^{\mathrm{b}} \\
2.253(0.047)^{\mathrm{b}} \\
2.778(0.047)^{\mathrm{d}}\end{array}$ & $\begin{array}{l}0.087(0.067)^{\mathrm{a}} \\
1.294(0.067)^{\mathrm{b}} \\
1.448(0.067)^{\mathrm{b}} \\
2.080(0.053)^{\mathrm{c}} \\
2.500(0.054)^{\mathrm{d}}\end{array}$ \\
\hline $\begin{array}{l}\text { Moisture } \\
(\% \text { wb) }\end{array}$ & \begin{tabular}{|l|} 
Raw meat \\
Mixed \\
Macerated \\
Smoked \\
Ripened
\end{tabular} & $\begin{array}{l}64.13(1.272)^{\mathrm{a}} \\
70.96(1.272)^{\mathrm{b}} \\
71.98(1.272)^{\mathrm{b}} \\
47.86(1.020)^{\mathrm{c}}(1.058)^{\mathrm{d}}\end{array}$ & $\begin{array}{l}69.00(1.065)^{\mathrm{a}} \\
68.76(1.065)^{\mathrm{a}} \\
68.62(1.065)^{\mathrm{a}} \\
60.88(0.825)^{\mathrm{b}} \\
54.07(0.825)^{\mathrm{c}}\end{array}$ & $\begin{array}{l}66.56(1.142)^{\mathrm{a}} \\
69.85(1.142)^{\mathrm{b}} \\
70.30(1.142)^{\mathrm{b}} \\
54.59(0.900)^{\mathrm{c}} \\
48.31(0.916)^{\mathrm{d}}\end{array}$ \\
\hline
\end{tabular}

Different superscript letters indicate differences $(p<0.05)$ of least square means sequentially between stages. 
In relation to the permissible amounts of additives in this type of sausages [22], their concentrations in sausages from Factory I were below the limits (sodium nitrite E250: 150 ppm; potassium nitrate E252: 150 ppm; and polyphosphates E452: 5000 ppm expressed as $\mathrm{P}_{2} \mathrm{O}_{5}$ ). However, chouriço from Factory II exceeded by far the maximum legal limits of nitrates (220 ppm) and polyphosphates (8890 ppm; Table 1). In fact, since nitrates are normally added in long, slow curing processes that necessitate a long-term reservoir for nitrite to be slowly released over the course of the process [23], their use is unnecessary in chouriço for the relatively-short production time of $\sim$ 3-4 weeks.

\section{Total viable counts along chouriço processing}

The evolution patterns of TVC in chouriço were different between factories, although, overall, the statistical analysis revealed a tendency for TVC to increase in each of the stages (Figure 2); and in table 2, notice the positive intercepts Day(Mixed), Day(Macerated), Day(Smoked) and Day(Ripened)). Figure 2 shows that the greatest increases were at the smoking and ripening stages, for Factory $\mathrm{l}$, and at the ripening stage only, for Factory II. Such increases in TVC are primarily due to the growth of lactic acid bacteria (LAB), which rapidly becomes the main microbial group as fermentation proceeds. Simultaneously, the production rate of organic acids becomes high enough to cause a significant drop in $\mathrm{pH}$ (Table 1), reason why an inverse association can be observed between TVC and $\mathrm{pH}$ in the general linear model (Table 2).

Contrarily to the anticipated, the mixing of raw meat with ingredients did not significantly reduced the TVC counts. A decrease was expected since the added condiments contain inhibitory compounds that would affect the viability and/or culturability of the microorganisms [24], as previously described by Linares et al. [25], when the antibacterial activity of garlic mixed with wine was demonstrated for macerating pork meat in the fabrication of a Portuguese chouriço type, and reiterated by the results of Gonzales-Barron et al. [2].

Considering only the nitrite-formulated sausages (Factory II), a slight decrease in TVC was observed during smoking. In fact, TVC should increase and approximate $L A B$ counts after maceration, when fermentations starts, so it can be suggested that the salt-nitrite combination used by Factory II may have induced a delay in the fermentation process, which did not happen in Factory I, as the TVC counts increased right after maceration. However, from the end of smoking, the effect of nitrite on TVC appeared to have ceased to be inhibitory. As the nitrite (in dry basis) in sausages concentrated, TVC continued to increase $(p<.0001$ in Table 2$)$, suggesting that the concentration of nitrite applied (mean $8.55 \mathrm{ppm}$ ) may have delayed the start of fermentation but had no inhibitory effect once LAB started developing. However, it is known that at input levels of $150 \mathrm{ppm}$, sodium nitrite is able to slightly slow down the formation of lactic acid [1].

The significant negative association between $\mathrm{pH}$ and TVC $(p<.0001$ in Table 2) suggests that, overall, as $\mathrm{pH}$ decreases (viz. fermentation taking place), TVC has an increasing trend.
The $\mathrm{pH}$ decrease is continuous throughout the process but it is more evident during smoking (Table 1). Likewise, the greatest increase in TVC occurred during that same step (Figure 2), in agreement with the usual development of LAB in dry fermented sausages, which displays a fast increase to $\sim 8$ log CFU/g during fermentation and then stabilises along ripening and storage [26].

Interaction between $\mathrm{pH}$ and nitrite $(\mathrm{p}<.0001$ in table 2$)$ was also extracted, since the stability of nitrite is $\mathrm{pH}$ dependent. As described before, phosphate addition to the cure increased the $\mathrm{pH}$ of the meat to a certain extent, and by this means, caused greater nitrite retention during processing. However, the bacteriostatic effect of nitrite is increased as the $\mathrm{pH}$ is lowered, as revealed by the negative estimate for the interaction between $\mathrm{pH}$ and nitrite.

Water activity and TVC showed a positive association (i.e., sausages with higher $a_{w}$ have higher TVC; $p=0.069$ in table 2 ). Still related to the water content and TVC in this type of product, previous results from Gonzales-Barron et al. [2] pointed out that the higher the polyphosphate concentration during mixing and the higher the moisture during maceration, the higher the TVC will be at the end of such processing stages.

From the longitudinal analysis shown in table 3 , the number of days that maceration and ripening took place had significant, factory-specific, effects on the TVC. For instance, the average increase in TVC per day of maceration was 0.256 $(p<.0001)$ in Factory I, and $0.510(p=0.010)$ in Factory II. Increases in TVC during maceration were expected as a consequence of the growth of lactic acid bacteria, as previously referred. The TVC increase observed in Factory I occurred since the $a_{w}$ of the product and the ripening temperature were able to support $L A B$ growth.

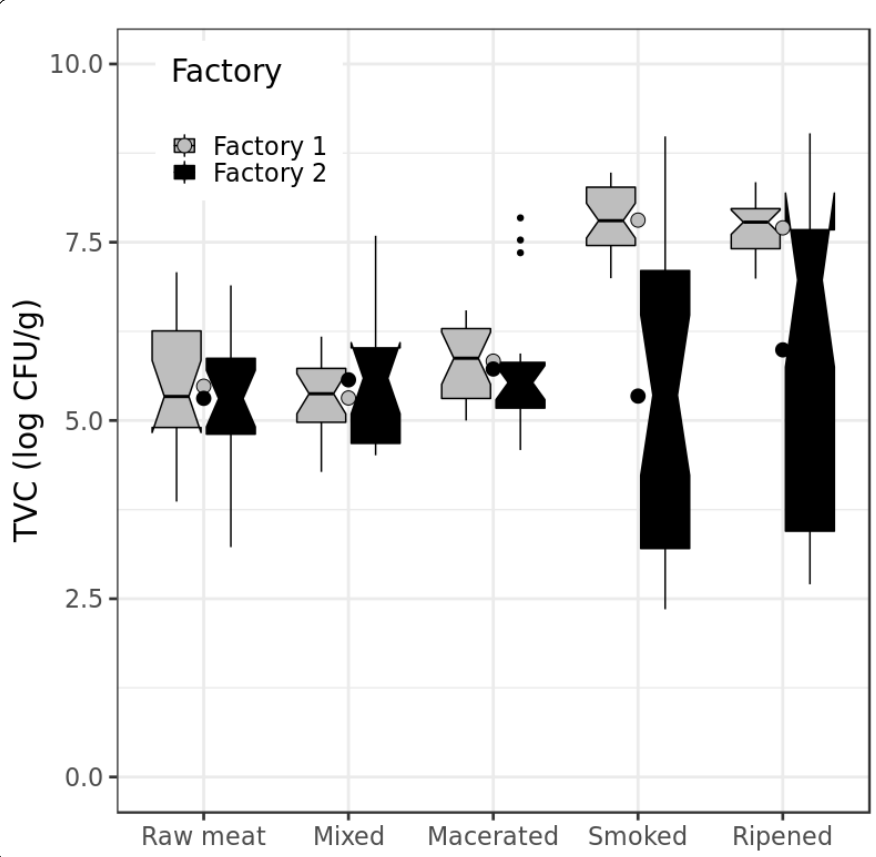

Figure 2. Factory-specific total viable counts (TVC) in meat along the different processing stages of dry-fermented chouriço sausages. Data dispersion is represented by boxplots, with median and mean indicated by the mid-horizontal line and circle marker respectively. 
Table 2. Parameter estimates of the generalised linear model assessing the overall effects of processing stage, $a_{w}, p H$ and sodium nitrite concentration ( $\mathrm{mg} / \mathrm{kg} \mathrm{db}$ ) on the total viable counts (TVC) and Enterobacteriaceae counts (log CFU/g) in chouriço sausages during production.

\begin{tabular}{|l|c|c|c|c|}
\hline \multirow{2}{*}{ Effect } & \multicolumn{2}{|c|}{ TVC } & \multicolumn{2}{c|}{ Enterobacteriaceae } \\
\cline { 2 - 5 } & Estimate (St. error) & $\mathrm{Pr}>|\mathrm{t}|$ & Estimate (St. error) & $\mathrm{Pr}>|\mathrm{t}|$ \\
\hline Intercept & $5.225(4.293)$ & 0.225 & $11.30(5.801)$ & 0.053 \\
Day & & & & \\
$\quad$ Mixed & $1.831(0.975)$ & 0.061 & $1.241(1.118)$ & 0.268 \\
Macerated & $0.154(0.041)$ & $<.0001$ & $0.115(0.048)$ & 0.017 \\
Smoked & $0.067(0.014)$ & $<.0001$ & $-0.013(0.015)$ & 0.391 \\
Ripened & $0.059(0.012)$ & $<.0001$ & $-0.352(0.014)$ & $<.001$ \\
$\mathrm{a}_{\mathrm{w}}$ & $8.319(4.551)$ & 0.069 & $11.50(5.301)$ & 0.031 \\
$\mathrm{pH}$ & $-1.451(0.248)$ & $<.0001$ & $-3.374(0.757)$ & $<.0001$ \\
$\mathrm{pH} \times$ Nitrites & $-0.959(0.115)$ & $<.0001$ & $0.685(0.156)$ & $<.0001$ \\
Nitrites & $5.724(0.675)$ & $<.0001$ & $-4.120(0.905)$ & $<.0001$ \\
\hline Covariance & & & & \\
Batch(Factory) & 0.838 & & 1.082 & \\
BIC & 650 & & 693 & \\
\hline
\end{tabular}

BIC: the Bayesian Information Criterion is a criterion for model selection among a set of models. Generally, the model with lowest $\mathrm{BIC}$ is the one preferred.

On a batch basis, there was no positive significant association between environmental contamination (TVC counted from environmental elements) and TVC levels in sausages (Table 3). In relation to ambient temperatures, a higher temperature in the maceration room was associated $p=0.049$ in table 3 to greater TVC counts. Higher relative humidity values in the mixing, maceration and ripening rooms were also associated with higher levels of TVC in chouriço along processing.

Table 3. Influence of processing days (Day) and environmental parameters (batch contamination level and room temperature/relative humidity) on the total viable counts and Enterobacteriaceae counts

(log CFU/g) recovered from chouriço sausages during production.

\begin{tabular}{|l|c|c|c|c|}
\hline \multirow{2}{*}{ Effect } & \multicolumn{2}{|c|}{ TVC } & \multicolumn{2}{c|}{ Enterobacteriaceae } \\
\cline { 2 - 5 } & Estimate (St. error) & $\operatorname{Pr}>|\mathrm{t}|$ & Estimate (St. error) & $\mathrm{Pr}>|\mathrm{t}|$ \\
\hline Day & & & & \\
Factory I & & & & \\
$\quad$ Maceration & $0.256(0.055)$ & $<.0001$ & $-0.030(0.095)$ & 0.752 \\
$\quad$ Smoking & $0.016(0.012)$ & 0.221 & $-0.144(0.022)$ & $<.0001$ \\
$\quad$ Ripening & $0.037(0.015)$ & 0.017 & $-0.007(0.026)$ & 0.797 \\
Factory II & & & & \\
Maceration & $0.510(0.195)$ & 0.010 & $0.181(0.112)$ & 0.109 \\
$\quad$ Smoking & $-0.083(0.096)$ & 0.394 & $-0.270(0.057)$ & $<.0001$ \\
$\quad$ Ripening & $-0.289(0.089)$ & 0.002 & $0.181(0.050)$ & $<.0001$ \\
\hline Environmental & & & & \\
contamination & & & & \\
Mean - all rooms & $-0.432(0.245)$ & 0.080 & $1.423(0.547)$ & 0.010 \\
Cutting room & $-0.296(0.122)$ & 0.018 & $0.540(0.333)$ & 0.108 \\
Mixing room & $-0.019(0.187)$ & 0.855 & $0.646(0.385)$ & 0.010 \\
Maceration room & $0.118(0.113)$ & 0.299 & $-0.374(0.373)$ & 0.318 \\
Temperature & & & & \\
Cutting room & $0.037(0.063)$ & 0.561 & $0.081(0.045)$ & 0.074 \\
Mixing room & $0.028(0.061)$ & 0.642 & $0.072(0.044)$ & 0.103 \\
Maceration room & $0.169(0.059)$ & 0.049 & $0.050(0.041)$ & 0.219 \\
Ripening room & $-0.094(0.045)$ & 0.039 & $0.065(0.033)$ & 0.050 \\
Relative humidity & & & & \\
Cutting room & $-0.002(0.023)$ & 0.917 & $0.042(0.017)$ & 0.014 \\
Mixing room & $0.108(0.026)$ & $<.0001$ & $0.023(0.019)$ & 0.217 \\
Maceration room & $0.064(0.028)$ & 0.024 & $-0.019(0.021)$ & 0.344 \\
Ripening room & $0.077(0.021)$ & $<.0001$ & $-0.024(0.015)$ & 0.123 \\
\hline
\end{tabular}

\section{Enterobacteriaceae counts along chouriço processing}

The initial Enterobacteriaceae numbers in raw pork were similar between factories (Figure 3) and within the range usually reported for this type of traditional meat products (3 to 4 log CFU/g) [27]. Although, in all batches surveyed, Enterobacteriaceae was inactivated during ripening, their evolution patterns were fairly dissimilar between factories (Figure 3).
For instance, in Factory l, Enterobacteriaceae counts decreased from raw meat to meat in batter, while in Factory II, between the same processing stages, the levels of this hygiene indicator increased and remain high until the end of maceration. The decrease observed during mixing in Factory I could be explained by the effect of spices' antimicrobial compounds [25] and the lower acidity environment (Table 1). On the other hand, the increase in Factory II may be due to the higher meat $\mathrm{pH}$ (which enables Enterobacteriaceae growth) caused by the addition of polyphosphate (i.e., increased moisture retention capability) and possibly cross-contamination from environment during mixing.

Another example of opposite behaviours of Enterobacteriaceae between factories is shown by the distinct effects of stuffing and smoking. In Factory II, the numbers of Enterobacteriaceae decreased significantly from $3.65 \mathrm{log}$ CFU/g before stuffing to $1.63 \mathrm{log}$ CFU/g after smoking (Figure 3). The hurdle that mainly hindered the activity of Enterobacteriaceae was the nitrite used in the formulation of sausages, which can be confirmed by the significant inverse effect of nitrite $(-4.120 ; p<.001$ in table 2) on Enterobacteriaceae as estimated by the generalised linear model. Smoking and temperature of smoking are also expected to have a negative impact on Enterobacteriaceae counts because of its proved antimicrobial effects on pathogenic members of this family (for example Escherichia coli 0157:H7, Salmonella Newport and Yersinia enterocolitica [28]). Smoke is able to inhibit, to a certain extent and for some time, the growth of microorganisms on the sausage surface as it contains volatile antimicrobial compounds such as short chain fatty acids and aldehydes [2]. In Factory I, after stuffing and smoking, smoked chouriço revealed an increase in Enterobacteriaceae counts from the numbers observed after maceration. This could be due to possible cross-contamination from operators, equipment and/ or casings during stuffing or an amplified competitiveness of Enterobacteriaceae (caused by the lack of nitrite) in relation to other microorganisms.

Currently, it is still not clear how nitrite can inhibit microbial growth. Nonetheless, it is know that under acidic conditions (during fermentation), nitrite is converted to several derivatives such as nitrous acid and nitric oxide, which have been pointed out as the actual responsible for the inhibitory effect of nitrite $[23,29]$. One of the hypotheses for this inhibitory effect is that the presence of nitrite under acidic conditions leads to a decreased intracellular $\mathrm{pH}$ compared to that of cells grown only under acidic stress. This would mean that intracellular acidification is a significant antibacterial effect of acidified nitrite [29].

Drying ( $a_{w}$ decline during smoking and ripening; table 1) caused the Enterobacteriaceae levels to decrease in both factories, as shown by the significant direct effect of $a_{w}$ (11.50; $\mathrm{p}=0.031$ in table 2). Sausage $\mathrm{pH}$ during processing was also heavily associated with Enterobacteriaceae counts $(p<.0001$ in table 2). In particular, during mixing and maceration, the higher $\mathrm{pH}$, caused by the addition of polyphosphates, resulted in higher Enterobacteriaceae numbers (Figure 3); similarly, in ripened sausages: the lower $\mathrm{pH}$ caused a reduction in Enterobacteriaceae numbers. 
From the longitudinal analysis, the duration of smoking significantly affected the survival of Enterobacteriaceae: in Factory I, an average of $0.144-\log$ decrease per day was observed, while in nitrite-formulated sausages, the average reduction was $0.270-\log$ per day (Table 3 ). The duration of ripening also showed a significant influence on the levels of Enterobacteriaceae but only in Factory II (Table 3), where an average increase of 0.181 -log per day can be observed.

On a batch level, higher levels of Enterobacteriaceae environmental contamination in the mixing room $(p=0.010)$, higher ambient temperatures in the ripening room $(p=0.050)$ and higher relative humidity in the cutting room $(p=0.014)$ were associated to greater numbers of Enterobacteriaceae in the final product (Table 3).

By combining all the above results, it is possible to rank the factors that favoured the growth of Enterobacteriaceae in macerated, smoked or ripened chouriço (Table 6). The five factors that prompted Enterobacteriaceae growth the most in the macerated, smoked or ripened product were the following: high numbers of Enterobacteriaceae after mixing $(p=0.001)$ and after smoking $(p=0.013)$, high $a_{w}$ at the end of smoking $(p=0.023)$, high numbers of Enterobacteriaceae in raw meat $(p=0.049)$ and cross-contamination from the smoking environment $(p=0.069)$. This analysis also showed that in batches of shorter smoking $(p=0.250)$ - thereby producing sausages of lower salt concentration in dry basis after smoking $(p=0.235)$ - Enterobacteriaceae numbers tended to be higher.

It is interesting to notice that nitrite-free sausages revealed higher Enterobacteriaceae levels than nitriteformulated sausages, as expected and showed by González \& Díez [27], but still comparable between them. This shows that without the addition of nitrite, the decrease of $\mathrm{pH}$ and $\mathrm{a}_{\mathrm{w}}$ the competition with $L A B$ and the presence of salt (in an adequate concentration) are hurdles enough to inhibit the growth of Enterobacteriaceae during chouriço ripening.

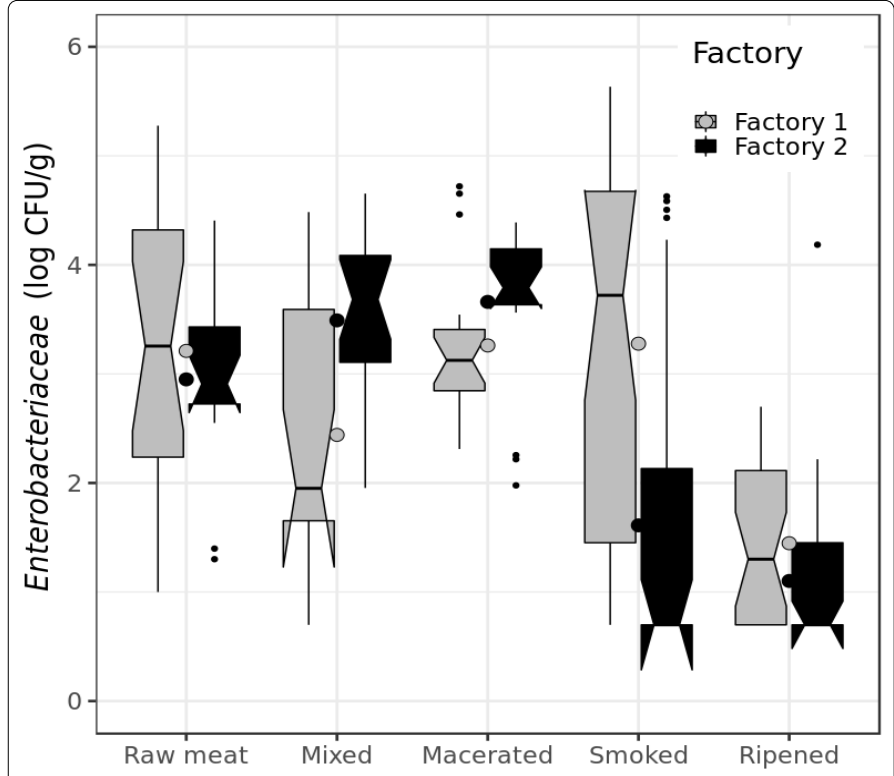

Figure 3. Factory-specific Enterobacteriaceae concentration in meat along the different processing stages of dry-fermented chouriço sausages. Data dispersion is represented by boxplots, with median and mean indicated by the mid-horizontal line and circle marker, respectively.

\section{S. aureus counts along chouriço processing}

Overall, the evolution patterns of this pathogen during production were similar between Factory I and II, with the greatest difference occurring at the smoking step only. In both factories, $S$. aureus was isolated from raw pork meat in numbers below $2 \log C F U / g$, a value that increased until the end of mixing and persisted even after maceration, regardless of the addition of nitrite. This shows that mixing is a critical point of the process that requires special attention in terms of good manufacturing practices since, at this stage, contamination is likely to be introduced from operators, poorly sanitised equipment/utensils and/or contaminated spices.

Since nitrite had no inhibitory effect on $S$. aureus levels at any stage, as shown by the significant positive intercept from the generalised linear model (2.256; $p=0.007$ in table 4), it is plausible that the increase observed after smoking in sausages from Factory I was caused by further contamination introduced by operators and/or equipment during stuffing. Contamination through casings is likely given the positive, although slight, association between this variable and $S$. aureus counts in the final product ( $p=0.205$; table 6$)$.

The introduction of high levels of contamination at the point of stuffing in Factory I made the smoke and significant decrease in $a_{w}$ during smoking (Table 1 ) insufficient to control S. aureus growth in the product. Additionally, as a mesophilic and halophilic bacterium, $S$. aureus is resistant to the high ambient temperatures used during smoking and the high salt concentrations in the product, respectively; the latter is supported by the significant negative association between $a_{w}$ and $S$. aureus in table $4(-14.48 ; p=0.001)$. These conditions were all favourable to the growth of this pathogen and resulted in the increase observed in Factory I. Oppositely, the slight reduction in S. aureus counts in Factory II during smoking (Figure 4) suggests that no contamination was introduced earlier in the process, reason why the smoke and significant $a_{w}$ decrease might have been sufficient to inhibit the growth of this pathogen. Reiterating the results described before, the outcomes of the generalised model show that this bacterium may survive and grow during mixing $(p=0.100)$ and maceration $(p=0.087)$ (Table 4).

Table 4. Parameter estimates of the generalised linear model assessing the overall effects of processing stage, $a_{w}, \mathrm{pH}$ and sodium nitrite concentration ( $\mathrm{mg} / \mathrm{kg} \mathrm{db}$ ) on Staphylococcus aureus and

Listeria monocytogenes concentration (log CFU/g) in chouriço sausages production.

\begin{tabular}{|l|c|c|c|c|}
\hline \multirow{2}{*}{ Effect } & \multicolumn{2}{|c|}{ Staphylococcus aureus } & \multicolumn{2}{c|}{ Listeria monocytogenes } \\
\cline { 2 - 5 } & Estimate (St. error) & $\operatorname{Pr}>|\mathrm{t}|$ & Estimate (St. error) & $\mathrm{Pr}>\mathrm{X}^{2}$ \\
\hline Intercept & $10.88(5.199)$ & 0.037 & $-7.447(11.04)$ & 0.500 \\
Day & $1.458(0.897)$ & 0.100 & $1.260(1.711)$ & 0.462 \\
Mixed & $0.065(0.038)$ & 0.087 & $0.044(0.059)$ & 0.448 \\
Macerated & $0.008(0.011)$ & 0.486 & $-0.198(0.055)$ & $<.0001$ \\
Smoked & $-0.033(0.011)$ & 0.003 & $-0.168(0.043)$ & $<.0001$ \\
Ripened & $-14.48(4.451)$ & 0.001 & $18.49(9.31)$ & 0.047 \\
$\mathrm{a}_{\mathrm{w}}$ & $0.811(0.611)$ & 0.186 & $-1.223(0.779)$ & 0.116 \\
$\mathrm{pH}$ & $-0.384(0.140)$ & 0.007 & - & - \\
$\mathrm{pH} \times$ Nitrites & $2.256(0.826)$ & 0.007 & $0.272(0.129)$ & 0.036 \\
Nitrites & & & & \\
\hline Covariance & & & 72.18 & \\
Batch(Factory) & 0.633 & & 212 & \\
BIC/Deviance & 533 & & & \\
\hline
\end{tabular}


As shown by the results in table 5 , each day of ripening had the following effect in S. aureus counts: in Factory 1, a 0.008 -log decrease ( $p=0.673)$; in Factory II, a 0.314-log decrease $(p<.0001)$. However, in figure 4, a slight increase can be observed for sausages from Factory II at the ripening stage. This may be a result of the sausages $\mathrm{pH}$ value that is positively associated with S. aureus counts $(0.811 ; p=0.186$ in table 4$)$, meaning that higher $\mathrm{pH}$ values imply less inhibitory effect on the growth of this pathogen, as previously described by Bang et al. [30]. The duration of the ripening period in this Factory may also have contributed to the survival of $S$. aureus, as it was short and maybe unable to counterbalance the $\mathrm{pH}$ effect. Summarising, in Factory II, the addition of polyphosphates caused an improper fermentation and $\mathrm{pH}$ decay, which drove the increase in $\mathrm{S}$. aureus during ripening. In this sense, it can be said that $\mathrm{pH}$ is a great obstacle hindering $\mathrm{S}$. aureus development, so a rapid $\mathrm{pH}$ decline is necessary early in fermentation. In both factories, the product's final $\mathrm{pH}$ was higher than the value indicated for suppressing $S$. aureus growth (5.3; $[19])$, meaning that the time and temperature at which the fermenting meat remains above $\mathrm{pH} 5.3$ is critical for controlling the growth of this pathogen.

Table 5. Influence of processing days (Day) and environmental parameters (batch contamination level and room temperature/ relative humidity) on the counts of $S$. aureus and $L$. monocytogenes (log CFU/g) recovered from chouriço sausages during production.

\begin{tabular}{|l|c|c|c|c|}
\hline \multirow{2}{*}{ Effect } & \multicolumn{2}{|c|}{ S. aureus } & \multicolumn{2}{c|}{ L. monocytogenes } \\
\cline { 2 - 5 } & Estimate (St. error) & $\operatorname{Pr}>|t|$ & Estimate (St. error) & $\operatorname{Pr}>\chi^{2}$ \\
\hline Day & & & & \\
Factory I & & & & \\
$\quad$ Maceration & $0.076(0.073)$ & 0.298 & $-0.039(0.119)$ & 0.742 \\
$\quad$ Smoking & $-0.037(0.017)$ & 0.032 & $-0.181(0.042)$ & $<.0001$ \\
Ripening & $-0.008(0.020)$ & 0.673 & $-0.157(0.034)$ & $<.0001$ \\
Factory II & & & & \\
Maceration & $-0.221(0.110)$ & 0.047 & $0.299(0.139)$ & 0.031 \\
Smoking & $-0.053(0.054)$ & 0.336 & $-0.282(0.072)$ & $<.0001$ \\
Ripening & $-0.314(0.051)$ & $<.0001$ & $-0.213(0.044)$ & $<.0001$ \\
\hline Environmental & & & & \\
contamination & & & & \\
Mean & $-a$ & $-a$ & $0.128(0.082)$ & 0.117 \\
Cutting room & - & - & $-b$ & $-b$ \\
Mixing room & - & - & - & - \\
Maceration room & - & - & - & - \\
Temperature & & & & \\
Cutting room & $0.054(0.047)$ & 0.263 & $-0.394(0.098)$ & $<.0001$ \\
Mixing room & $0.043(0.052)$ & 0.400 & $0.010(0.038)$ & 0.786 \\
Maceration room & $0.082(0.042)$ & 0.055 & $-0.307(0.065)$ & $<.0001$ \\
Ripening room & $0.136(0.033)$ & $<.0001$ & $-0.378(0.071)$ & $<.0001$ \\
Relative humidity & & & & \\
Cutting room & $-0.035(0.023)$ & 0.078 & $0.136(0.025)$ & $<.0001$ \\
Mixing room & $-0.015(0.022)$ & 0.494 & $0.080(0.031)$ & 0.011 \\
Maceration room & $-0.001(0.026)$ & 0.958 & $0.125(0.021)$ & $<.0001$ \\
Ripening room & $0.002(0.018)$ & 0.904 & $0.238(0.036)$ & $<.0001$ \\
\hline
\end{tabular}

aThe model could not estimate these parameters as $S$. aureus mean environmental contamination was not different from batch to batch. bThe model could not estimate these parameters because environmental data partitioned by room rendered $L$. monocytogenes mean concentrations having very low batch-to-batch variation.

On a batch level, higher ambient temperatures in the maceration $(p=0.055)$ and ripening rooms $(p<.0001)$ were associated to higher counts of $S$. aureus in the final product (Table 5). No significant association between relative humidity and $S$. aureus levels in sausages was observed (Table 5).

From the surveys' data, it is possible to rank the risk factors influencing the growth of $S$. aureus in smoked or ripened chouriço as follows (Table 6): low moisture after smoking $(p=0.008)$, high $S$. aureus concentration after smoking $(p=0.019)$, low salt concentration after smoking $(p=0.021)$; high ambient temperature during maceration $(p=0.034)$ and low $a_{w}$ after smoking $(p=0.035)$.

Even though there is plenty of opportunities for improvement in terms of safety for this product, it is important to acknowledge that, in both factories, $S$. aureus was present in the final product at levels below $3 \log$ CFU/g, value at which enterotoxin formation does not occur (the critical concentration for toxin production is around $7 \log$ CFU/g [30]).

\section{L. monocytogenes counts along chouriço processing}

Since the presence of $L$. monocytogenes in the meat samples occurred at low concentrations and with uneven distribution, their recoveries by sampling were associated with great variability. For this reason, statistical analyses for this microorganism were based on the Poisson-gamma regression models, where concentrations (response variable) were used directly as CFU instead of log-transformed, and zero counts (absence in $25 \mathrm{~g}$ ) entered the models as such (for an in-depth discussion on the advantages of applying Poisson-gamma count data models in the analysis of lowcounts microbial data, see Gonzales-Barron et al. [15]).

The initial contamination by L. monocytogenes in raw meat was comparable and low in both factories. However, the evolution pattern was very distinct between factories and among batches (Figure 5). In all batches from Factory I, the levels of this pathogen remained generally low $(<50 \mathrm{CFU} / \mathrm{g})$ during all stages of processing, which can be a result of the rapid acidification profile of these sausages (lower $\mathrm{pH}$ values inhibit $L$. monocytogenes growth). It can also be a consequence of a better equipment and facilities hygiene, since this pathogen is frequentlyan environmental contaminant. In comparison, batches from Factory II showed a significant increase in L. monocytogenes during mixing and maceration for one batch in particular, also during smoking. It is likely that this increase was a consequence of contamination entering at the point of mixing through poorly-disinfected equipment, working surfaces and/or the addition of spices. Since in Factory II the pH drop was smaller and slower than desirable (due to the presence of polyphosphates), the $\mathrm{pH}$ value of the product at these stages was higher than in Factory I, which could have created the appropriate conditions and contributed to the growth of the pathogen during mixing and maceration. This hypothesis is aligned with the results of Samelis et al, [31] and Gonzales-Barron et al. [2] who recovered listeriae and L. monocytogenes in particular, respectively, from fermented sausages during the early days of processing in batches characterised by higher $\mathrm{pH}$ values. Moreover, ICMSF [19] pointed out that, if a fermentation delay occurs, L. monocytogenes can grow in the sausage mix, as it happened in batches from Factory II. Since the association between Temperature-Maceration and $L$. monocytogenes counts is positive and significant $(p=0.031$ in table 5), it can be speculated that the low temperature was not enough to overcome the high $\mathrm{pH}$ effect. The one batch from Factory II that still presented high contamination levels during smoking could be the result of major contamination entering at the previous processing stages (mixing, maceration and stuffing) that the 
smoke and high temperatures were not able to reduce below the value of $250 \mathrm{CFU} / \mathrm{g}$ (Figure 5). Despite the specific batch discussed above, overall, in both factories, L. monocytogenes was inactivated during smoking and ripening (Figure 5), likely due to the high temperatures during the first and the low temperature-low relative humidity during the second. Similar results regarding the effects of smoking but for another type of dry-fermented sausage were obtained by Gonzales-Barron et al. [2] and Hajmeer et al. [28].
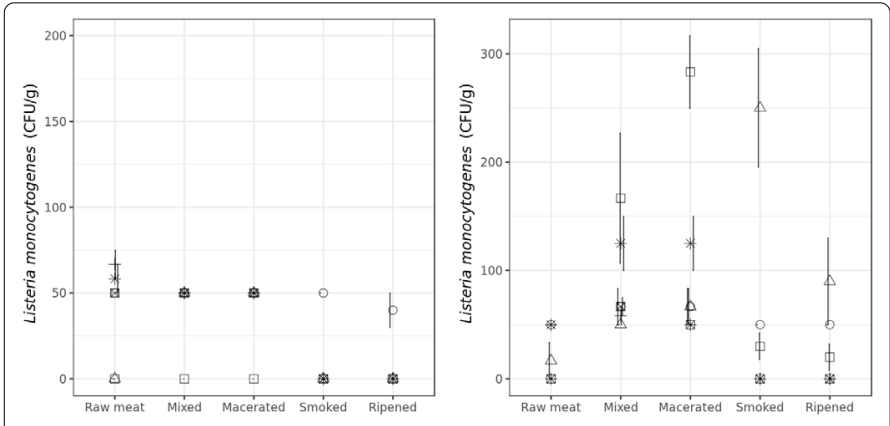

Figure 5. Batch-specific L. monocytogenes concentration in meat along the different processing stages of dry-fermented chouriço sausages sampled from Factory I (left) and Factory II (right). Each marker represents within-batch mean and standard error, and different batches are indicated by different markers.

Table 6. Main risk factors (process variables, intrinsic characteristics, environmental and raw materials contamination) contributing to the growth/survival of Enterobacteriaceae, S. aureus and

L. monocytogenes in the macerated meat, smoked and ripened chouriço sausages produced in the surveyed factories, as pinpointed by stepwise variable selection analyses.

\begin{tabular}{|c|c|c|c|c|}
\hline Bacterial group & Stepwise-selected variables a & Partial R2 & F-value & $\operatorname{Pr}>\mathrm{F}$ \\
\hline Enterobacteriaceae & $\begin{array}{l}\text { Macerated } \\
\text { Enterobact. after mixing }(+) \\
\text { pH of raw meat }(+) \\
\text { Smoked } \\
\text { Enterobact. in raw meat }(+) \\
\text { Enterobact in environment }(+) \\
\text { Enterobact. after macerat }(+) \\
\text { Moisture after smoking }(+) \\
\text { pH after smoking }(+) \\
\text { Temperature of maceration }(+) \\
\text { Salt after smoking }(-) \\
\text { Days of smoking }(-) \\
\\
\text { Ripened } \\
\text { Enterobact. after smoking }(+) \\
\mathrm{a}_{\mathrm{w}} \text { after smoking }(+) \\
\text { Days of ripening }(+) \\
\text { Enterobact in environment }(+)\end{array}$ & $\begin{array}{l}0.105 \\
0.188 \\
0.179 \\
0.156 \\
0.151 \\
0.144 \\
0.137 \\
0.122 \\
\\
0.476 \\
0.368 \\
0.257 \\
0.237\end{array}$ & $\begin{array}{l}5.34 \\
4.26 \\
2.69 \\
2.04 \\
1.78 \\
1.68 \\
1.59 \\
1.49\end{array}$ & $\begin{array}{l}0.001 \\
0.095 \\
\\
0.049 \\
0.069 \\
0.135 \\
0.187 \\
0.210 \\
0.224 \\
0.235 \\
0.250 \\
\\
0.013 \\
0.023 \\
0.092 \\
0.108\end{array}$ \\
\hline S. aureus & $\begin{array}{l}\text { Macerated } \\
\text { S. aureus after mixing (+) } \\
\text { pH of macerating meat }(+) \\
\text { Days of maceration }(-) \\
\text { TVC in casings (+) } \\
\text { Smoked } \\
\text { Moisture after smoking (-) } \\
\text { Salt after smoking (-) } \\
\text { Added nitrate }(-) \\
\text { Temperature maceration (+) } \\
\text { S. aureus in raw meat }(+) \\
\text { Moisture after maceration }(-) \\
\text { Temperature cutting room (+) } \\
\text { Ripened } \\
\text { S. aureus after smoking }(+) \\
\text { Temperature maceration }(+) \\
\text { aw after smoking }(-) \\
\text { pH after smoking }(+) \\
\text { Days of ripening }(-) \\
\text { pH of raw meat }(+) \\
\text { S. aureus in casings }(+) \\
\text { S. aureus in the mix }(+)\end{array}$ & $\begin{array}{l}0.341 \\
0.207 \\
0.183 \\
0.174 \\
\\
0.563 \\
0.462 \\
0.339 \\
0.291 \\
0.135 \\
0.078 \\
0.100 \\
\\
\\
0.477 \\
0.408 \\
0.290 \\
0.221 \\
0.197 \\
0.105 \\
0.112 \\
0.073 \\
\end{array}$ & $\begin{array}{l}4.65 \\
3.06 \\
2.15 \\
1.90 \\
\\
11.6 \\
7.74 \\
4.62 \\
3.69 \\
2.05 \\
1.74 \\
1.13\end{array}$ & $\begin{array}{l}0.059 \\
0.123 \\
0.181 \\
0.201 \\
\\
0.008 \\
0.021 \\
0.060 \\
0.087 \\
0.189 \\
0.224 \\
0.250\end{array}$ \\
\hline
\end{tabular}

\begin{tabular}{|l|l|c|c|c|}
\hline & Macerated & & & \\
& L. mono. in mix (+) & 0.885 & 77.4 & $<.0001$ \\
& Temperature maceration (-) & 0.504 & 10.15 & 0.010 \\
& pH of macerating meat (+) & 0.336 & 5.07 & 0.048 \\
& Added nitrites (-) & 0.020 & 1.90 & 0.201 \\
& & & \\
& & & \\
& Smoked & & \\
& Temperature cutting room (-) & 0.528 & 11.2 & 0.008 \\
& L. mono in casings (+) & 0.223 & 2.88 & 0.120 \\
& a after smoking (+) & 0.222 & 2.86 & 0.122 \\
& pH of meat (+) & 0.137 & 1.59 & 0.236 \\
& Days of maceration (-) & 0.108 & 1.35 & 0.250 \\
& & & & \\
& Ripened & & & \\
& L. mono after smoking (+) & 0.906 & 97.2 & $<.0001$ \\
& Temperature cutting room (-) & 0.396 & 6.56 & 0.028 \\
& L. mono in casings (+) & 0.347 & 5.31 & 0.044 \\
& Days of production (-) & 0.261 & 3.53 & 0.090 \\
& pH of macerating meat (+) & 0.211 & 2.67 & 0.133 \\
& L. mono in raw meat (+) & 0.015 & 1.71 & 0.223 \\
& Moisture after smoking (+) & 0.141 & 1.65 & 0.228 \\
& a after smoking (+) & 0.072 & 1.71 & 0.232 \\
\hline
\end{tabular}

aPositive (+) or negative (-) association between variables.

In this study, the Poisson-gamma regression evidenced the significant inhibitory effects of nitrite and $a_{w}$ on $L$. monocytogenes along processing $(p=0.036$ and $p=0.047$ in table 4, respectively). These factors, combined with the adequate $\mathrm{pH}$ evolution and final value (lower than 5.3, as previously referred [19]) as well as the appropriate process duration, should be enough to control the growth of this pathogen and ensure safer products. In this sense, the duration of smoking and ripening also showed a significant impact on the final counts of $L$. monocytogenes in both factories $(p<.0001$, table 5$)$, meaning that batches of short smoking period or short ripening period would likely be associated with greater survival of $L$. monocytogenes in smoked or ripened sausages, respectively. This result can be verified by the differences in $L$. monocytogenes contamination in sausages from both factories: with shorter smoking and ripening durations (in addition to other influencing factors different from Factory I previously discussed), some batches from Factory Il did present higher counts of this microorganism at those processing stages. The maceration extent was also meaningful in Factory II but in this case, the longer the duration, the higher the counts.

On a batch level, the temperature of the cutting room revealed an inverse significant association with the level of $L$. monocytogenes contamination ( $p<.0001$, table 5). Similarly, and despite the low ambient temperatures used during maceration and ripening, growth of this pathogen was still possible (negative association with $p<.0001$, table 5). Higher relative humidity values throughout the process were also associated with higher levels of $L$. monocytogenes (Table 5).

The factors influencing significantly $L$. monocytogenes growth in macerated, smoked or ripened chouriço, as identified in this study, are ranked as follows (Table 6): L. monocytogenes concentration in the mixture and after smoking $(p<.0001$ in both cases), ambient temperature of the cutting room $(p=0.008)$, ambient temperature of the maceration room $(p=0.010)$, L. monocytogenes contamination in casings $(p=0.044)$ and $\mathrm{pH}$ of the macerating meat $(p=0.048)$.

As stated before, $L$. monocytogenes is more often a contaminant present in the environment than in the raw meat itself. For this reason, it should not be difficult to implement 
better hygiene practices and improve the method of production so that fermentation problems are avoided and the microbiological safety of chouriço is ensured, thus preventing listeriosis outbreaks.

\section{Conclusions}

The mixing and maceration stages were found to be critical points of the production process of Portuguese chouriço sausages since Enterobacteriaceae, $S$. aureus and $L$. monocytogenes increased significantly until the end of such stages in the batches from Factory II. With these results, it is plausible that the manufacturing and hygiene practices implemented at that factory, as well as the sanitisation of equipment/utensils, may not be adequate for the safe production of chouriço.

Sausages from Factory II were formulated with nitrite and polyphosphate concentrations above the legal limits and the analyses performed revealed that their fermentation process was suboptimal. In fact, the presence of such additives caused delayed fermentation and higher $\mathrm{pH}$ levels that were responsible, to a certain extent, for the increase in Enterobacteriaceae and pathogens' counts during maceration. By contrast, the better acidification process of sausages from Factory I led to lower counts of $S$. aureus and L. monocytogenes in the final products.

Nitrite had a strong effect on reducing Enterobacteriaceae during smoking and also contributed to the control of $L$. monocytogenes. S. aureus, however, was not affected by nitrite. In Factory II, the growth of S. aureus was encouraged by the improper fermentation (caused by the presence of polyphosphates) that maintained the meat's $\mathrm{pH}$ above the value that inhibits growth $(\mathrm{pH}=5.3)$ for too long. $L$. monocytogenes entered the production process at the point of mixing, most likely due to cross-contamination with the environment, yet the pathogen became progressively inactivated throughout smoking and ripening, despite the undesirable $\mathrm{pH}$.

Factors contributing to the control of $S$. aureus, as determined in this study, are: rapid $\mathrm{pH}$ drop early in fermentation, lower ambient temperature during maceration, lower meat's $\mathrm{pH}$, and lower contamination of casings. In relation to $L$. monocytogenes, three main hurdles (tested in this study) were found to prevent its growth: low $\mathrm{a}_{\mathrm{w}}$ low $\mathrm{pH}$ and nitrite. Other factors that contribute to controlling this pathogen in sausages are: longer ripening and smoking periods, lower ambient temperature of the cutting and maceration rooms, lower L. monocytogenes contamination in casings, and lower $\mathrm{pH}$ of the macerating meat.

From this study, it can be concluded that the microbiological safety and stability of chouriço depends on a combination of several hurdles. Moreover, it is clear the importance of standardising the productive process of chouriço, since currently, the high variability identified between factories and also within batches from the same factory are factors greatly responsible for the unpredictable quality and safety of this product. In order to minimise the introduction of Enterobacteriaceae and pathogens from external sources into the process, it is imperative to control the quality of all ingredients and materials (for example, spices and casings), to ensure the sanitisation of equipment and utensils, and to guarantee good hygiene practices from operators.

\section{Acknowledgments}

Gonzales-Barron wishes to acknowledge the financial support provided by the Portuguese Foundation for Science and Technology (FCT) through the award of a five-year Investigator Fellowship (IF) in the mode of Development Grants (IF/00570).

\section{References}

1. Lucke FK. Fermented meats (Chapter 19). In: The Microbiological Safety and Quality of Foods (Edition Lund BM, Baird-Parker TC, Gould GW (Edition), Aspen Publishers. 2000; 1: 420-444.

2. Gonzales-Barron U, Cadavez V, Pereira AP, et al. Relating physicochemical and microbiological safety indicators during processing of linguiça, a Portuguese traditional dry-fermented sausage. Food Res Int. 2015; 78: 5061. doi: 10.1016/j.foodres.2015.11.007

3. Roseiro LC, Gomes A, Goncalves H, Sol M, Cercas R, Santos C. Effect of processing on proteolysis and biogenic amines formation in a Portuguese traditional dry-fermented ripened sausage "Chouriço Grosso de Estremoz e Borba PGI". Meat Sci. 2010; 84(1): 172-179. doi: 10.1016/j. meatsci.2009.08.044

4. Elias M, Potes ME, Roseiro LC, Santos C, Gomes A, Agulheiro-Santos AC The effect of starter cultures on the Portuguese traditional sausage "Paio do Alentejo" in terms of its sensory and textural characteristics and polycyclic aromatic hydrocarbons profile. J Food Res. 2014; 3: 45-56. doi: 10.5539/jfr.v3n3p45

5. Marcos C, Viegas C, Almeida AM, Guerra MM. Portuguese traditional sausages: different types, nutritional composition and novel trends. J Ethn Foods. 2016; 3(1): 51-60. doi: 10.1016/j.jef.2016.01.004

6. Xavier C, Gonzales-Barron U, Paula V, Estevinho L, Cadavez V. Metaanalysis of the incidence of foodborne pathogens in Portuguese meats and their products. Food Res Int. 2014; 55: 311-323. doi: 10.1016/j. foodres.2013.11.024

7. ISO. Horizontal method for the detection and enumeration of Listeria monocytogenes - part 2: Enumeration method. Amendment 1: Modification of the enumeration medium. ISO 11290-2:1998/Amd. 1:2004(E). International standards microbiology of food and animal feeding stuffs. Geneva, Switzerland: International Organization for Standardization, 1998.

8. ISO. Horizontal method for the detection and enumeration of Listeria monocytogenes - part 1: Detection method. Amendment 1: Modification of the isolation media and the haemolysis test, and inclusion of precision data. ISO 11290-1:1996/Amd. 1:2004(E). International standards microbiology of mood and animal feeding stuffs. Geneva, Switzerland: International Organization for Standardization, 1996a.

9. ISO. Determination of moisture content. ISO 1442. International standards meat and meat products. Geneva, Switzerland: International Organisation for Standardisation, 1997.

10. ISO. Determination of chloride content - Part 1: Volhard method. ISO 1841-1. International standards meat and meat products. Geneva, Switzerland: International Organisation for Standardisation, 1996b.

11. ISO. Determination of nitrite content. ISO 2918. International standards meat and meat products. Geneva, Switzerland: International Organisation for Standardisation, 1975a. 
12. ISO. Determination of nitrate content. ISO 3091. International standards meat and meat products. Geneva, Switzerland: International Organisation for Standardisation, $1975 b$

13. AOAC. Phosphorous (total) in meat. Official Method 969.31 Washington, USA: Association of Official Analytical Chemistry. AOAC International, 1995.

14. Clesceri LS, Greenberg AE, Trussell RR. Standard Methods for the Examination of Water and Wastewater, 20th edition; Washington: American Public Health Association (Section 4500 P-E), 1998.

15. Gonzales-Barron U, Cadavez V, Butler F. Conducting inferential statistics forlow microbial counts in foods using the Poisson-gamma regression. Food Control. 2014; 37: 385-394. doi: 10.1016/j.foodcont.2013.09.032

16. SAS Institute Inc. 2013. Base SAS ${ }^{\circledR} 9.4$ Procedures Guide. Cary, NC: SAS Institute Inc.

17. R Core Team. R: a Language and Environment for Statistical Computing. 2017.

18. Pearson AM, Gillett TA. Processed meats. Chapter 11, 3rd edition. Maryland: Aspen Publishers; 1996.

19. ICMSF. Microorganisms in Foods 6. Microbial Ecology of Food Commodities: Chapter 1, 2nd edition. New York: Kluwer Academic; 2005.

20. AMS. Good manufacturing practices for fermented dry and semi-dry sausages; Washington DC: American Meat Institute, 1997.

21. García-Fontán MC, Lorenzo JM, Martínez S, Franco I, Carballo J. Microbiologicalcharacteristics of Botillo, a Spanish traditional pork sausage. LWT-Food Sci Technol. 2007; 40(9): 1610-1622. doi: 10.1016/j. Iwt.2006.10.007

22. Anonymous. Commission Regulation (EU) No 1129/2011 of 11 November 2011 amending Annex II to Regulation (EC) No 1333/2008 of the European Parliament and of the Council by establishing a union list of food additives. Official Journal of the European Union, L295. 2011.
23. Sebranek J, Bacus J. Natural and organic cured meat products: regulatory, manufacturing, marketing, quality and safety issues. White paperseries, 1, American Meat Science Association, 2007.

24. Ducic M, Blagojevic B, Markov S, Velicanski A. General patterns of background microbiota and selected bacterial pathogens during production of fermented sausages in Serbia. Food Control. 2014; 43: 231237. doi: 10.1016/j.foodcont.2014.03.026

25. Linares MB, Garrido MD, Martins C, Patarata L. Efficacies of garlic and $L$. sakei in wine-based marinades for controlling Listeria monocytogenes and Salmonella spp. in Chouriço de Vinho, a dry sausage made from winemarinated pork. J Food Sci. 2013; 78(5): 719-724. doi: 10.1111/17503841.12094

26. Hospital XF, Hierro E, Fernández M. Effect of reducing nitrate and nitrite added to dry fermented sausages on the survival of Salmonella Typhimurium. Food Res Int. 2014; 62: 410-415. doi: 10.1016/j. foodres.2014.03.055

27. González B, Díez V. The effect of nitrite and starter culture on microbiological quality of "chorizo"-a Spanish dry cured sausage. Meat Sci. 2002; 60(3): 295-298. doi: 10.1016/S0309-1740(01)00137-1

28. Hajmeer MN, Tajkarimi M, Gomez EL, et al. Thermal death of bacterial pathogens in linguiça smoking. Food Control. 2011; 22(5): 668-672. doi: 10.1016/j.foodcont.2010.07.027

29. Müller-Herbst S, Mühlig A, Kabisch J, Pichner R, Scherer S. The food additives nitrite and nitrate and microbiological safety of food products. Am J Microbiol. 2015; 6(1): 1-3. doi: 10.3844/ajmsp.2015.1.3

30. Bang W, Hanson DJ, Drake MA. Effect of salt and sodium nitrite on growth and enterotoxin production of Staphylococcus aureus during the production of air dried fresh pork sausage. J Food Prot. 2008; 71(1): 191195.

31. Samelis J, Metaxopoulos J, Vlassi M, Pappa A. Stability and safety of traditional Greek salami-a microbiological ecology study. Int J Food Microbiol. 1998; 44(1-2): 69-82. 